\title{
Analysis of the prevalence of different topographical characteristics of the residual ridge in mandibular free-end arches
}

\section{Análise da prevalência de diferentes características topográficas do rebordo residual em arcos mandibulares com extremidades} livres

\author{
Carlos Gramani Guedes* \\ Artêmio Luiz Zanetti** \\ Pedro Paulo Feltrin***
}

\begin{abstract}
This study observed the prevalence of different types of residual ridge inclination in free-ends of mandibles and reported possible correlative factors that may affect resorption. For this purpose, periapical radiographs and individual data collected from a sample of 64 hemiarches were used. Two radiographs were taken of each freeend, and tracing was employed to determine the angles formed by the resorption configuration in the area of the $1^{\text {st }}$ mandibular molar. The following conclusions were drawn: 1) the great majority of alveolar ridges were distally descending; 2) the average angle was wider for users of mandibular removable partial dentures; 3) the results obtained suggest that the type of opposing maxillary arch affects the inclination of mandibular ridges; 4) greater inclination was observed when the $2^{\text {nd }}$ bicuspids of the mandible were the abutment teeth; 5) no significant correlation was established between age, sex and residual ridge resorption.
\end{abstract}

DESCRIPTORS: Denture, partial, removable; Radiography.

\begin{abstract}
RESUMO: Esta pesquisa constatou a prevalência dos tipos de rebordos residuais no sentido ântero-posterior em extremidades livres inferiores, além de correlacionar alguns fatores que possam influenciar as suas reabsorções. Para isso, utilizamos radiografias periapicais e dados individuais colhidos na amostra de 64 hemiarcos; foram obtidas 2 radiografias de cada área de extremidade livre e, a partir de traçados, determinamos os ângulos formados pela reabsorção na altura do $1^{\circ}$ molar inferior. Podemos constatar que: $1^{\circ}$ ) a grande maioria de inclinação encontrada foi de rebordos descendentes para distal; $2^{\circ}$ ) a média de angulação foi maior para usuários de prótese parcial removivel inferior; $3^{\circ}$ ) os resultados sugeriram existir influência do tipo de arco antagônico superior na inclinação dos rebordos inferiores; $4^{\circ}$ ) observou-se aumento de inclinação quando os segundos pré-molares inferiores eram os dentes adjacentes ao espaço protético; e $5^{\circ}$ ) não foram encontradas correlações significantes entre idade, sexo e reabsorção do rebordo residual.
\end{abstract}

DESCRITORES: Prótese parcial removivel; Radiografia.

\section{INTRODUCTION}

Free-end removable partial dentures (RPDs), especially mandibular ones, continue to challenge practitioners in the field of dental prosthetics not only on account of their biomechanical complexity, for they are supported by two distinct types of tissue (dental and fibromucosal), but also in view of the high failure rate observed with this type of denture in rehabilitative oral treatment.

The free-end fibromucosal support system is of major importance not only because of the increased exposure to forces as teeth are gradually lost but also as a result of the difference in mechanical operation between the edentulous area and the support teeth. It is acknowledged, nonetheless, that the alveolar bone is the true support for such forces ${ }^{2}$.

The morphology of the alveolar bone in the residual ridge is directly affected by anatomical and systemic factors, masticatory habits and the wearing of dentures ${ }^{3}$. Pietrokovski ${ }^{23}$ (1975) gauged the density of the residual ridge bone and observed that it is intermediate between that of the trabecular bone inside the mandible and that of the cortical bone of the outer casing. The bone available in the posterior edentulous area of the mandible, according to the Misch ${ }^{20}$ (1999) classification, con-

\footnotetext{
* Adjunct Professor, Department of Dentistry, University of Brasilia.

** Chair Professor, Department of Dental Prosthesis, University of São Paulo.

*** Senior Lecturer, Department of Dental Prosthesis, City of São Paulo University.
} 
Guedes CG, Zanetti AL, Feltrin PP. Analysis of the prevalence of different topographical characteristics of the residual ridge in mandibular free-end arches. Braz Oral Res 2004;18(1):29-34.

sists of thick, dense or porous cortical bone at the crest of the ridge and fine trabecular bone inside, in addition to another type of bone of lower density displaying thin, porous cortical bone at the ridge and encasing a fine trabecular bone.

Nevertheless, biomechanical studies show that mandibular removable partial dentures (RPDs) in action form a system of levers on the fibromucosal tissue in which the abutment tooth acts as a rotational fulcrum, while the angle of inclination of the ridge forms a slanted plane system, which increases proportionally to the inclination of the residual ridge and may cause deflections at the point where bite force is applied ${ }^{19,26}$.

Although the form of residual ridge is affected by the type of fibromucosal support in each individual, this is the real support for the RPD. Studying the angle is therefore relevant to aid prosthodontists in designing prosthetic devices and also to supply valuable data for research on the biomechanical behaviour of dentures subjected to bite force.

\section{METHODOLOGY \\ Selection of sample}

Patients were selected from clinics run by the Discipline of Dentistry, University of Brasilia, based on the presence of uni- or bilateral free-ends when the abutment teeth were mandibular cuspids or $2^{\text {nd }}$ bicuspids, whether or not the patients wore mandibular RPDs. All the individuals examined reported good health and had no systemic disturbances when the selection took place. A total of 64 hemiarches were classified by the consecutive method, divided into two groups of 32 hemiarches for each situation, of both genders and from different age groups. Cases in which the $1^{\text {st }}$ bicuspid was the abutment tooth were excluded from the sample, since the intention was to investigate the relation between the sagittal length of the edentulous segment and the degree of inclination. All the individuals selected were informed about the research and signed a declaration of consent, duly approved by the Ethics \& Research Committee.

\section{Casts and tooth arrangement}

Plaster casts were obtained for all the patients, on which an acrylic resin denture base was made and artificial teeth were arranged. The occlusal plane was used as a reference in all the casts, standardised by tracing an imaginary line through the incisal angle of the cuspid to the end of the $2^{\text {nd }}$ third of the retromolar $\operatorname{pad}^{26,28}$, as shown in
Figure 1. Base points were created by setting $3 \mathrm{~mm}$ ball-bearings at the end of the $2^{\text {nd }}$ third of the retromolar pad, fixed in the internal part of the resin base. The central cavity of the $1^{\text {st }}$ artificial molar was used as the base reference point for measuring this angle; another ball-bearing was set under this area. This region was chosen because it receives a greater magnitude of bite force ${ }^{16}$, and is more likely to have greater resorption since the $1^{\text {st }}$ permanent molars are the first to be extracted from the mandible ${ }^{13}$.

\section{Radiographic shots}

The radiographic shots were taken on ultrarapid periapical film (Kodak Ektaspeed Plus, EP$21 \mathrm{P}$, type 2, Rochester, New York, USA), with a 0.7 second exposure time. The area radiographed extended from the cuspid to the retromolar pad, and the artificial tooth-base appliance was positioned in the mouth. Since this is a considerable area to be radiographed, occlusal film (Kodak Ektaspeed occlusal radiographic film, Rochester, New York, USA) was used, cut lengthwise in a darkroom and spliced using dark isolating tape.

The radiographic technique employed was the parallel technique with the aid of a film-holder/ positioner (Jon brand radiographic positioner, São Paulo, Brazil) and a long-cone locator. For each hemiarch 2 radiographic shots were taken, as recommended by El Basty, Eid ${ }^{10}$ (1985). Since full occlusal or incisal surfaces were required, cases in which the remaining teeth did not possess adequate clinical crowns or had crowns diverging from the occlusal plane were eliminated from the sample. Tooth extrusions in the maxillary arch

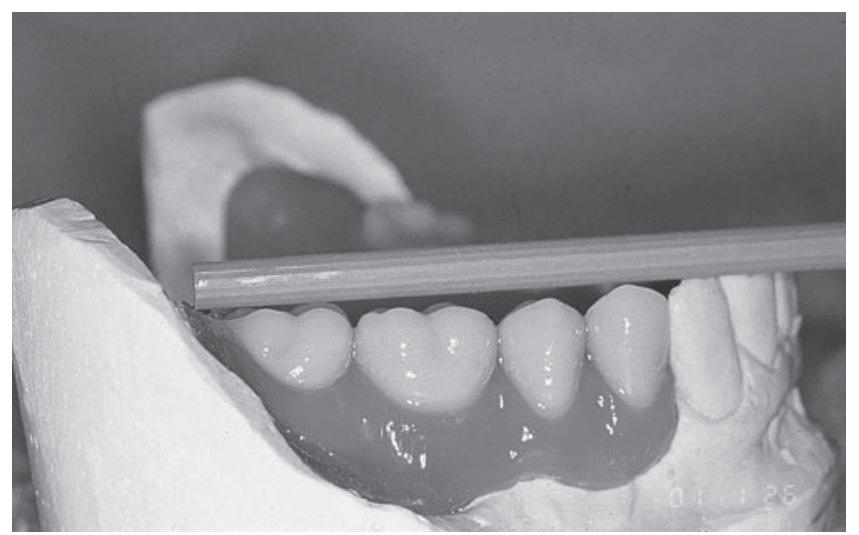

FIGURE 1 - Sagittal view of mandible arch plaster cast with artificial teeth mounted. Note the occlusal plane obtained by the points of reference (tip of canine cusp and end of $2^{\text {nd }}$ third of the retromolar pad). 
Guedes CG, Zanetti AL, Feltrin PP. Analysis of the prevalence of different topographical characteristics of the residual ridge in mandibular free-end arches. Braz Oral Res 2004;18(1):29-34.

were likewise corrected by abrasion or prosthetic means to prevent them from interfering in the positioning of the artificial denture base for the radiographic shots in occlusion.

The radiographs were developed by the visual method and assessed by a single observer in a dark environment. They were subsequently fixed on tracing paper to obtain the tracings.

\section{Tracings}

A straight line $\mathrm{AB}$ was traced corresponding to the occlusal reference plane (Figure 2a).

Using a ruler and a square, a line was traced parallel to the AB segment, using the distal alveolar crest of the abutment tooth as a reference to determine the individual's current bone loss (point C) (Figure $2 b$ ).

A line was traced perpendicular to the refer- ence plane, joining the lowest point of the sphere placed at the $1^{\text {st }}$ molar level to the highest point of the edentulous segment (line DE) (Figure 2c).

A line was then traced from point $\mathrm{C}$ to point $\mathrm{E}$ to form the angle $\mathrm{DCE}$, thus measuring the ridge inclination angle (Figure 2d).

\section{RESULTS AND DISCUSSION}

From the results obtained, it can be observed that among the 64 hemiarches examined, there were only 3 cases of distally ascending ridges and 1 case of a horizontal (i.e. $0^{\circ}$ inclination) ridge, with respective prevalences of $4.68 \%$ and $1.56 \%$. Distally descending ridges presented a general average inclination of $17.95^{\circ}\left(19.8^{\circ}\right.$ when $2^{\text {nd }}$ bicuspids were the abutment teeth and $16.10^{\circ}$ when cuspids were the abutment teeth).

These data help elucidate certain aspects

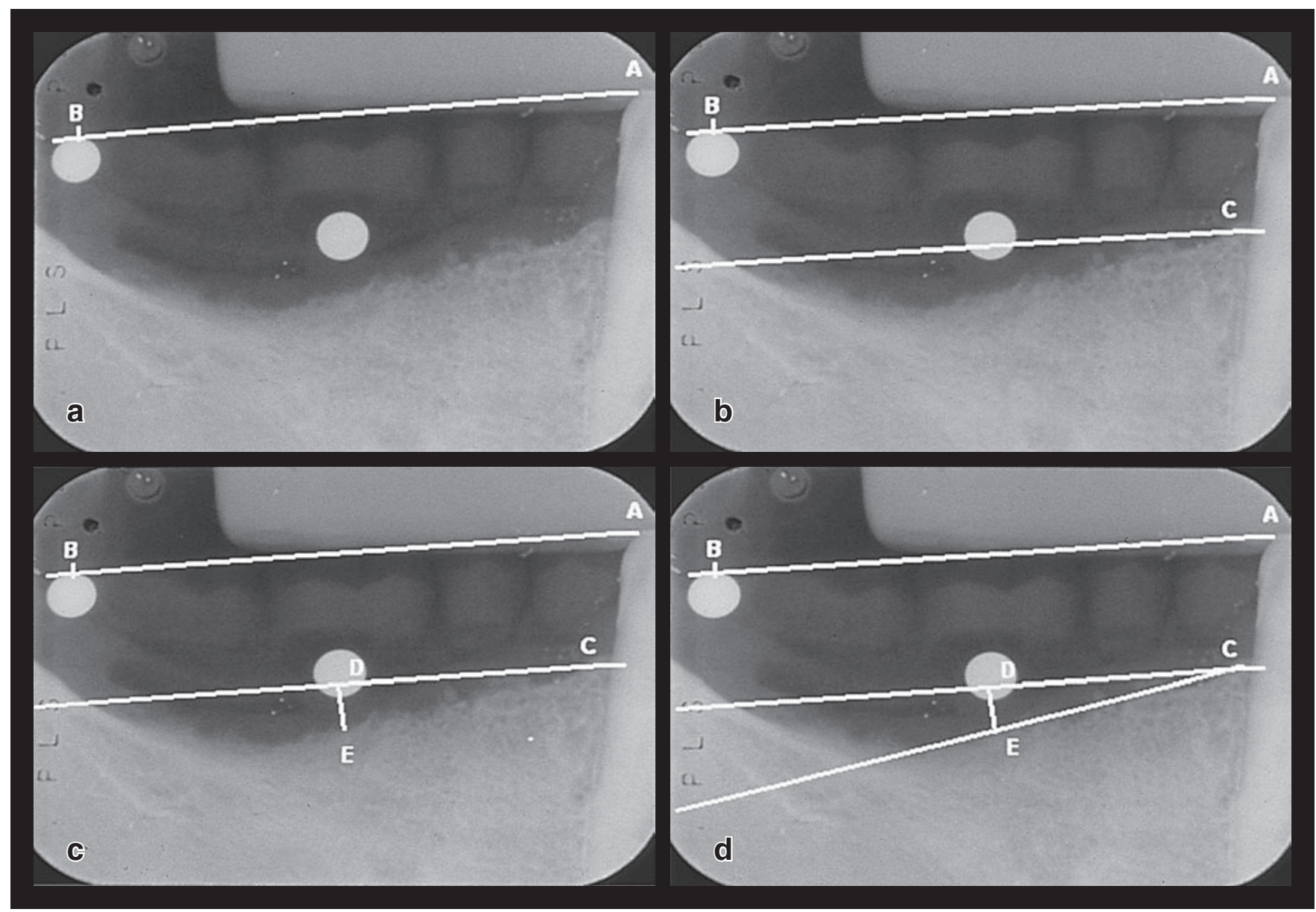

FIGURE 2 - a) radiographic image with tracing representing the occlusal plane (line segment AB); b) line segment parallel to the occlusal plane taking the distal alveolar crest of the abutment tooth (point C) as the point of reference; c) line traced perpendicular to the occlusal plane parallel (line segment DE); d) tracing of line CE to form angle DCE corresponding to the ridge inclination angle. 
Guedes CG, Zanetti AL, Feltrin PP. Analysis of the prevalence of different topographical characteristics of the residual ridge in mandibular free-end arches. Braz Oral Res 2004;18(1):29-34.

described in the literature. Elbrecht ${ }^{11}$ (1943) and Zanetti, Laganá ${ }^{29}$ (1988) observe that the inclination of the residual ridge directly affects the force exerted on it, producing a distal effect on distally descending ridges when a mandibular RPD is subjected to bite force transmitted in the form of compression. Cecconi et al. ${ }^{7}$ (1971), Christidou et al. ${ }^{8}$ (1973), Plotinick et al. ${ }^{24}$ (1975) and Feingold et al. ${ }^{12}$ (1988) use experimental data to emphasise that ridge inclination affects the movement of the abutment tooth of a mandibular RPD.

The sagittal inclination measurements obtained for each hemiarch and the individual data recorded for patients (type of opposing arch, use of mandibular RPD, abutment tooth, age and sex) were tabulated and processed statistically by variance analysis.

Table 1 shows that, in the sample examined, there was greater resorption (and consequently a wider angle) among patients using mandibular RPDs (19.3 ${ }^{\circ}$ on average) than among non-users of mandibular dentures $\left(16.47^{\circ}\right)$. This can be explained by the lever systems formed by free-end dentures in action ${ }^{19}$, as well as by the direct, proportional relation observed between the length of use of the RPD and bone resorption ${ }^{3,5,6,23}$. It should be stressed that the average resorption angle was not negligible (approximately $16.5^{\circ}$ ) among nonwearers of mandibular removable partial dentures. This finding may corroborate the theory of atrophy due to disuse ${ }^{1}$, reduced mechanical stimulus failing to provide the necessary conditions for normal remodelling.

The relation between the type of opposing arch and denture use and angle of resorption is shown in Tables 1 and 2, which show a patently greater level of resorption for natural teeth and maxillary removable partial dentures in comparison to complete dentures in the superior arch. From a biomechanical perspective, this finding suggests that the magnitude of pressure the opposing arch exerts is directly related to resorption of the residual ridge in the lower arch. This is in line with the findings Plotinick, Beresin ${ }^{24}$ (1975) recorded. The results likewise confirmed a lower level of resorption with complete dentures in the opposing arch because the bite forces among patients are considerably smaller ${ }^{14}$.

The recording of wider angles when the $2^{\text {nd }}$ bicuspid is the abutment tooth (Table 3) can be explained by the shorter distance between the measurement points. Figure 3 shows that the shorter the distance between the points - by the rules of the tangent for the rectangular triangle - the wider the angle obtained. Therefore, if free-ends where cuspids are the abutment teeth are compared with free-ends where $2^{\text {nd }}$ bicuspids serve as the abutment teeth, it is geometrically logical to expect the angle to be wider in the second case.

Table 3 shows a clearly significant statistical difference in resorption between users and nonusers of mandibular RPDs when the cuspid is the abutment tooth. A variety of explanations for this phenomenon are found in literature. These include: the effect of dentures on residual ridge morphol$\mathrm{ogy}^{23}$; poor proprioceptive reaction of the fibromucosal membrane, which fails to signal occlusal

TABLE 1 - Average measurements (in degrees) of angles under diverse conditions and critical figure (threshold) for contrast.

\begin{tabular}{|c|c|c|c|}
\hline \multicolumn{3}{|c|}{ Opposing arch } & \multirow{2}{*}{$\begin{array}{c}\text { Tukey } \\
5 \%\end{array}$} \\
\hline $\begin{array}{l}\text { Natural } \\
\text { teeth }\end{array}$ & $\begin{array}{c}\text { Complete } \\
\text { denture }\end{array}$ & RPD & \\
\hline 17.65 & 16.05 & 19.95 & 2.63 \\
\hline \multicolumn{3}{|c|}{ Denture use } & \multirow{6}{*}{2.37} \\
\hline Yes & & & \\
\hline 19.30 & & & \\
\hline \multicolumn{3}{|c|}{ Abutment tooth } & \\
\hline Cuspid & \multicolumn{2}{|c|}{ Bicuspid } & \\
\hline 16.10 & \multicolumn{2}{|c|}{19.67} & \\
\hline
\end{tabular}

RPD: removable partial denture.

TABLE 2 - Average measurements (in degrees) for main factors (opposing arch and denture use) and critical figure (threshold) for contrast.

\begin{tabular}{|c|c|c|c|c|}
\hline \multirow{2}{*}{$\begin{array}{c}\text { Denture } \\
\text { use }\end{array}$} & \multicolumn{3}{|c|}{ Opposing arch } & \multirow{2}{*}{$\begin{array}{c}\text { Tukey } \\
5 \%\end{array}$} \\
\hline & $\begin{array}{c}\text { Natural } \\
\text { teeth }\end{array}$ & $\begin{array}{c}\text { Complete } \\
\text { denture }\end{array}$ & RPD & \\
\hline Yes & 20.00 & 15.80 & 22.10 & \multirow{2}{*}{4.53} \\
\hline No & 15.30 & 16.30 & 17.80 & \\
\hline
\end{tabular}

RPD: removable partial denture.

TABLE 3 - Average measurements (in degrees) for main factors (abutment tooth and denture use) and critical figure (threshold) for contrast.

\begin{tabular}{l|c|c|c}
\hline \hline \multirow{2}{*}{ Abutment tooth } & \multicolumn{2}{|c|}{ Denture use } & \multirow{2}{*}{$\begin{array}{c}\text { Tukey } \\
5 \%\end{array}$} \\
\cline { 2 - 3 } & Yes & No & \\
\hline Cuspid & 18.53 & 13.67 & \multirow{2}{*}{3.32} \\
\hline Bicuspid & 20.07 & 19.27 & \\
\hline \hline
\end{tabular}


Guedes CG, Zanetti AL, Feltrin PP. Analysis of the prevalence of different topographical characteristics of the residual ridge in mandibular free-end arches. Braz Oral Res 2004;18(1):29-34.

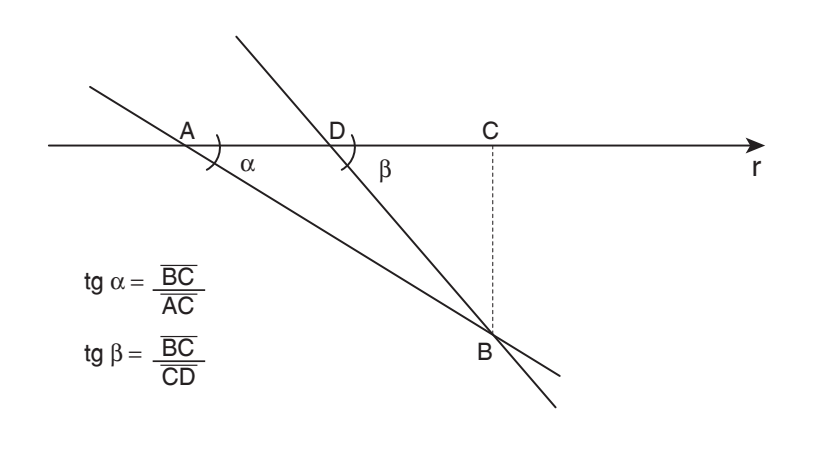

FIGURE 3 - Schematic illustration showing that the proximity of the reference points increases the denominator through calculation of the tangent for the rectangular triangle, registering a wider angle.

overload of the supporting tissues ${ }^{9}$ and provokes excessive pressure on the bone and mucosa, which in turn impairs circulation of the blood; the osteocytes become unable to supply the tissues with sufficient oxygen ${ }^{4}$, or even prostaglandin synthesis by the cells of the fibromucosal membrane is jeop$\operatorname{ardized}^{21}$. The most obvious explanation, however, is the lever effect a mandibular RPD produces, the force moment exerted increasing proportionally to the distance between the point where the pressure is applied and the rotational fulcrum ${ }^{25,29}$.

Tables 4 and 5 show that among women the angle of resorption is discreetly increased. Although Helkimo et al. ${ }^{15}$ (1977) detected less bite force among women, non-mechanical factors may be associated with this phenomenon. These include calcium mobilisation due to hormonal causes, especially estrogen deficiency during and after menopause ${ }^{17,27}$.

Furthermore, regarding the interpretation of data in Table 4, a slight difference was observed in patients over 60 years old in comparison to younger patients. Nonetheless, data in Table $5-$ which compares the use of dentures and the age of individuals - failed to show greater resorption among patients over 60 years of age, from which, in fact, a less pronounced angle was recorded. These findings may be explained by what Owall et al. ${ }^{22}$ (1997) consider to be a diminished masticatory capacity among older patients leading to less compression of the bone tissue as a result of diminished muscular activity. Klemetti ${ }^{18}$ (1994) has observed that reduced bone density is to be expected in women
TABLE 4 - Measurements (in degrees) of angles according to sex, age and supporting tooth.

\begin{tabular}{l|c|c|c|c}
\hline \hline \multirow{2}{*}{ Sex } & \multicolumn{2}{|c|}{ Abutment tooth } & \multicolumn{2}{c}{ Age } \\
\cline { 2 - 5 } & Cuspid & Bicuspid & $\begin{array}{c}<60 \\
\text { years }\end{array}$ & $\begin{array}{c}>60 \\
\text { years }\end{array}$ \\
\hline Female & 18.00 & 19.50 & 19.19 & 22.00 \\
\hline Male & 12.30 & 18.75 & 18.75 & 20.50 \\
\hline \hline
\end{tabular}

TABLE 5 - Measurements (in degrees) of angles according to denture use, sex and age.

\begin{tabular}{l|c|c|c|c}
\hline \hline \multirow{2}{*}{$\begin{array}{c}\text { Denture } \\
\text { use }\end{array}$} & \multicolumn{2}{|c|}{ Sex } & \multicolumn{2}{c}{ Age } \\
\cline { 2 - 5 } & Female & Male & $<60$ years & $>60$ years \\
\hline Yes & 18.50 & 16.00 & 19.62 & 19.50 \\
\hline No & 17.23 & 14.12 & 17.00 & 15.88 \\
\hline \hline
\end{tabular}

after the menopause but is not regularly encountered in older men, amongst whom there are even cases of increased bone density. Therefore, in light of the results obtained and the findings recorded in literature, it cannot be claimed that there is a cause-effect relation between resorption of the residual ridge and age.

\section{CONCLUSIONS}

Given the methodology employed, the measurements recorded and the statistical treatment of the data produced, it is reasonable to conclude that:

1. There is a prevalence of distally descending free-end mandibular residual ridges.

2. There is a statistically significant wider angle of distally descending ridges among users of mandibular RPDs than among non-users, and this difference is more evident when cuspids are the abutment teeth.

3. The results suggest that the magnitude of ridge inclination among users of mandibular RPDs is affected by the type of opposing maxillary arch.

4. Ridge inclinations were, on average, more pronounced when $2^{\text {nd }}$ bicuspids, as opposed to cuspids, were the abutment teeth, regardless of the use of mandibular RPDs.

5. No significant data were found to correlate age and sex, in isolation from other factors, to residual ridge resorption. 
Guedes CG, Zanetti AL, Feltrin PP. Analysis of the prevalence of different topographical characteristics of the residual ridge in mandibular free-end arches. Braz Oral Res 2004;18(1):29-34.

\section{REFERENCES}

1. Applegate OC. An evaluation of the support for the removable partial denture. J Prosthet Dent 1960;10:112-23.

2. Applegate OC. Evaluating oral structures for removable partial dentures. J Prosthet Dent 1961;11:882-5.

3. Atwood DA, Coy WA. Clinical, cephalometric, and densitometric study of reduction of residual ridges. J Prosthet Dent 1971;26:280-95.

4. Beerstecher E Jr, Bell RW. Some aspects of the biochemical dynamics in the periodontal ligament and alveolar bone resulting from traumatic occlusion. J Prosthet Dent 1974;32:646-50.

5. Carlsson GE, Hedegärd B, Koivumma KK. Studies in dental prosthesis. IV. Final results of a 4-year longitudinal investigation of dentogingivally supported partial dentures. Acta Odontol Scand 1965;23:443-72.

6. Carlsson GE, Ragnarson N, Astränd P. Changes in height of the alveolar process in edentulous segments. Svenk Tand Tid 1969;62:125-36.

7. Cecconi BT, Asgar K, Dootz E. Removable partial denture abutment tooth movement as affected by inclination of residual ridges and type of loading. J Prosthet Dent 1971;25:375-81.

8. Christidou L, Osborne J, Chamberlain JB. The effects of partial denture design on the mobility of abutment teeth. Br Dent J 1973;135:9-18.

9. Crum RJ, Rooney GE. Alveolar bone loss in overdentures: a 5-year study. J Prosthet Dent 1978;40:610-3.

10. El Basty S, Eid HI. The shape of the rest seat preparation and the percentage of alveolar bone loss of cuspid abutments receiving indirect retainers in lower bilateral free-end saddle cases. Egypt Dent J 1985;31:63-81.

11. Elbrecht A. De la próthesis parcial y de su construcción. Trib Odontol 1943;31:15-32.

12. Feingold GM, Grant A, Johnson W. The effect of variation of residual ridge angle on partial denture abutment tooth movement. J Oral Rehabil 1988;15:379-84.

13. Glisic B. Analysis of factors influencing the amount and localisation of residual ridge reduction of mandible. Stomatol Glas Srb 1989;36:419-26.

14. Haraldson T, Karlsson V, Carlsson GE. Bite force and oral function in complete denture wearers. J Oral Rehabil
1979;6:41-8.

15. Helkimo E, Carlsson GE, Helkimo M. Bite force and state of dentition. Acta Odontol Scand 1977;35:297-303.

16. Howell AM, Brüdevold F. Vertical forces used during chewing of food. J Dent Res 1950;29:133.

17. Jahangiri L, Devlin H, Ting K, Nishimura I. Current perspectives in residual ridge remodeling and its clinical implications: a review. J Prosthet Dent 1998;80:224-37.

18. Klemetti E, Vainio P, Lassilla V. Mineral density in the mandibles of partially and totally edentate postmenopausal women. Scand J Dent Res 1994;102:64-7.

19. Kratochvil FJ. Influence of occlusal rest position and clasp design on movement of abutment teeth. J Prosthet Dent 1963;13:114-24.

20. Misch CE. Implant Dentistry. $2^{\text {nd }}$ ed. St. Louis: Mosby; 1999.

21. Nishimura I, Szabo G, Flynn E, Atwood DA. A local pathophysiologic mechanism of the resorption of residual ridges: prostaglandin as a mediator of bone resorption. J Prosthet Dent 1988;60:381-8.

22. Owall B, Käyser AF, Carlsson GE. Prótese dentária: princípios e condutas estratégicas. São Paulo: Artes Médicas; 1997.

23. Pietrokovski J. The bony residual ridge in man. J Prosthet Dent 1975;34:456-62.

24. Plotinick IJ, Beresin VE. The effects of variations in the opposing dentition on changes in the partially edentulous mandible. Part 1. Bone changes observed in serial radiographs. J Prosthet Dent 1975;33:278-84.

25. Shaw FG. Simple levers and partial dentures. Part 1. Dent Tech 1968;24:24-7.

26. Stewart TK, Rudd KD, Kubker WA. Clinical removable partial prosthodontics. St. Louis: Mosby; 1983.

27. Xie Q, Ainamo A, Tilvis R. Association of residual ridge resorption with systemic factors in home-living elderly subjects. Acta Odontol Scand 1997;55:299-305.

28. Weinberg LA. Atlas of removable partial denture prosthodontics. St. Louis: Mosby; 1969.

29. Zanetti AL, Laganá DC. Planejamento: prótese parcial removivel. São Paulo: Sarvier; 1988.

Received for publication on Mar 20, 2003

Sent for alterations on Aug 22, 2003

Accepted for publication on Dec 03, 2003 